\title{
Legacies of pre-industrial land use can bias modern tree-ring climate calibrations
}

\author{
Björn E. Gunnarson ${ }^{1,2, *}$, Torbjörn Josefsson ${ }^{3}$, Hans W. Linderholm ${ }^{4}$, Lars Östlund ${ }^{1}$ \\ ${ }^{1}$ Department of Forest Ecology and Management, Swedish University of Agricultural Sciences, 90183 Umeå, Sweden \\ ${ }^{2}$ Department of Physical Geography and Quaternary Geology, Stockholm University, 10691 Stockholm, Sweden \\ ${ }^{3}$ Landscape Ecology Group, Department of Ecology and Environmental Science, Umeå University, 90187 Umeå, Sweden \\ ${ }^{4}$ Regional Climate Group, Department of Earth Sciences, University of Gothenburg, 40530 Gothenburg, Sweden
}

\begin{abstract}
In Scandinavia, dendrochronological reconstructions of past climate have mostly been based on tree-ring data from forests in which there has been, supposedly, very little or no human impact. However, human land use in sub-alpine forests has a substantially longer history and more profound effects on the forest ecosystems than previously acknowledged. Therefore, to assess human influence on tree-ring patterns over the last $500 \mathrm{yr}$, we have analyzed tree-ring patterns using trees from 2 abandoned Sami settlements and a reference site with no human impactall situated in the Tjeggelvas Nature Reserve in north-west Sweden. The hypothesis was that landuse legacies have affected tree-ring patterns, and in turn, the resulting palaeoclimate inferences that have been made from these patterns. Our results show that climate signals are strongest at the reference site and weakest at one of the settlement sites. From the 1940s to the present, tree growth at this settlement site has been significantly lower than at the reference site. Lower tree growth at old settlements may have resulted from rapid changes in the traditional land use, or following the abrupt change when the settlements were abandoned. Without site-specific knowledge of past land use, there is a high risk of accidently sampling trees that have been affected by human-induced disturbances in the past. This may create bias in the climate signals inferred from such trees, and hence bias the outcome of climate reconstructions. We therefore recommend sampling several separate sites in study areas to improve the robustness of inferences.
\end{abstract}

KEY WORDS: Scots pine - Tree-rings - Maximum latewood density - Climate reconstruction · Human land use $\cdot$ Vegetation history

\section{INTRODUCTION}

A number of millennial-length reconstructions of hemispheric-to-global temperatures have enhanced our knowledge of the climate and its variability in the past, which is increasingly important in the context of anticipated global warming (Jones et al. 1998, Mann et al. 1999, Esper et al. 2002). These reconstructions have been based on combinations of natural climate indicators - proxies - most importantly tree-ring data, since they offer annual resolution and extensive spatial coverage. Furthermore, more precise descriptions of regional climatic or palaeoenvironmental variability and change have been derived from networks of similarly averaged tree-ring chronologies, allowing large-scale reconstructions with spatiallyexplicit patterns of change (Gouirand et al. 2008). However, given the high priority of climate change research, the accuracy of proxies used is of major importance.

The robustness of tree-ring data relies on careful selection of trees. Ideally, data should be collected from trees growing close to their upper altitudinal or latitudinal limits, since such trees are highly sensitive to summer temperatures (cf. Briffa et al. 1992). In northernmost parts of Europe the tree-ring width 
(TRW) is primarily correlated with mid-summer (July) temperature, while the maximum latewood density (MXD) is strongly associated with temperatures over the full length of the growing season (McCarroll et al. 2003, Grudd 2008, Gunnarson et al. 2011). Peak response for the growing season is found with temperatures from August and is related to development of latewood cells. While TRW may provide information on other climate and environmental influences, such as precipitation or duration of snow cover, MXD provides stronger and more robust signals of the warm-season temperatures and is thus a more powerful proxy for summer temperatures than TRW.

Collecting tree-ring data from forests at high altitudes or latitudes is also preferable since they are often located in inaccessible areas, where direct anthropogenic disturbance, which can affect treegrowth patterns, has been (and still is) limited (Sano et al. 2009). In northern Fennoscandia, large numbers of dendrochronological analyses have been performed to improve reconstructions of past climate using tree-ring data from Scots pine Pinus sylvestris L. trees growing in remote sub-alpine forests (Briffa et al. 1990, 1992, Eronen et al. 2002, Grudd et al. 2002, Gunnarson \& Linderholm 2002, Helama et al. 2002, McCarroll et al. 2003, Gouirand et al. 2008, Grudd 2008, Tuovinen et al. 2009, Linderholm et al. 2010a,b, Gunnarson et al. 2011). Many such forests are considered as 'pristine', i.e. as having very limited or no human impact. However, an increasing body of evidence indicates that human land use in sub-alpine Scandinavian forests has had a substantially longer history and more profound effects on forest structure, ecological processes and ecosystem function than previously acknowledged (Hicks 1995, Hörnberg et al. 1999, Karlsson et al. 2009, Josefsson et al. 2010b). Furthermore, previous studies have shown that effects of past land use can reverberate through ecosystems for many centuries, and be almost imperceptible to the human eye at present (Foster et al. 2003, Josefsson et al. 2009).

In this study focusing on the last $500 \mathrm{yr}$, we analyzed and compared tree-ring patterns between an area with no apparent history of human land use and 2 areas in which human activity is known to have occurred until the early 20th century (around settlements of the Sami: an indigenous people of northernmost Europe). The study was conducted in the Tjeg- gelvas Nature Reserve (NR), which encompasses a vast forest landscape that is 'pristine', in that it has never been affected by forest management, but has some of the highest concentrations of Sami land-use remains in Scandinavia. Our hypothesis was that legacies of low-intensity and long-term land use have affected ring patterns of trees growing close to settlement sites, and have consequently biased the climate signals that can be inferred from them. Our analysis also forms the basis for a discussion regarding the importance of land-use history in palaeoclimatological research.

\section{STUDY AREA}

The study was carried out in the northern part of the Tjeggelvas NR, situated on the Arctic Circle in northern Sweden (Fig. 1). Due to its remoteness and inaccessibility, human land use in the forest landscape encompassing our study area has been low throughout the 20th century. The forest has never been commercially logged and is merely used as a transit area for reindeer herds as they migrate between their winter grazing grounds in the southeast and summer pastures in the northwest (Rönnow 1944). The Sami reindeer herders generally spend little time travelling with the herd and allow the reindeer to roam freely as they pass through the area during late spring and early autumn. For these reasons, the forest of the Tjeggelvas NR has been

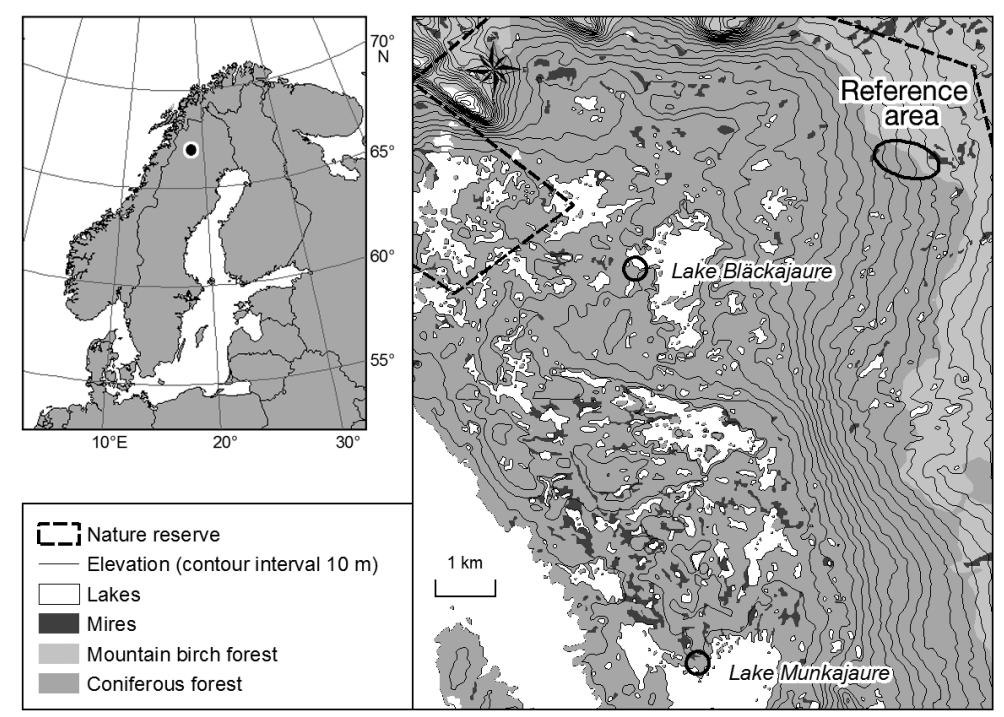

Fig. 1. Study area showing sampling sites near Bläckajaure, Munkajaure and Reference area. Reproduced with permission from Lantmäteriverket 1998. From GSD-Roadmap, dnr I 2010/0054 
regarded as one of the best examples of truly pristine Scots pine forest in Northern Europe. However, recent multidisciplinary studies have shown that this forest landscape was utilized by Sami reindeer herders before the early 20th century. Typically, their land use covered large areas and was of lowintensity, including gathering of natural resources and cutting trees for firewood and wooden constructions (cf. Hicks 1995, Berg et al. 2011a). The herders practiced intensive year-round herding and selective breeding and were in total control of the life cycle of their reindeer. The settlement and movement patterns, like with many other indigenous peoples in Eurasia, were defined by seasonal movements between areas that provided good pasture (Ruong 1945). Clearly, this type of reindeer herding was dramatically different from the extensive reindeer herding applied throughout the 1900s and today. Previous research has shown that the old, low-intensive form of land use could lead to changes in forest structure and tree species composition that are still apparent, especially around settlement sites and certain areas used regularly for extracting natural resources (Östlund et al. 2003, Josefsson et al. 2010b).

Scots pine forests such as those in the Tjeggelvas NR were utilized by the reindeer herders during winter and springtime (cf. Josefsson et al. 2010a). Within the study area there are 2 abandoned, naturally reforested settlement sites, one situated on the shores of Lake Bläckajaure and the other on the shores of Lake Munkajaure. Dendrochronological dating of trees with human-induced scars (Fig. 2) and analysis of fossil pollen derived from peat suggest that both settlements were established in the early 17 th century and abandoned during the early 20th century (Josefsson et al. 2009, Liedgren et al. 2009). While the settlement near Bläckajaure was used temporarily, predominately during winter and spring, the settlement near Munkajaure was more permanent, as indicated by numerous finds of dated archaeological remains (Josefsson et al. 2009, 2010b, Liedgren et al. 2009).

The climate in the region encompassing the Tjeggelvas NR is cool temperate, with mean monthly temperatures of -16 and $12^{\circ} \mathrm{C}$ in January and July, respectively, and mean annual precipitation of $530 \mathrm{~mm}$ (Alexandersson \& Eggertsson Karlström 2001). The terrain is hilly and the elevation ranges from 450 to $600 \mathrm{~m}$ a.s.l., generally rising to the east. Soils are nutrient-poor, mainly coarse-textured tills, underlain by migmatized granitoids, with younger granite and pegmatite intrusions (Fredén 1994). The forest, which is 300 to $400 \mathrm{yr}$ old and of low productivity, is domi- nated by Scots pine with scattered trees of downy birch Betula pubescens Ehrh., and occasionally Norway spruce Picea abies (L.) Karst. The mean elevation of the present Scots pine tree line is $\sim 600 \mathrm{~m}$ a.s.l.

\section{MATERIALS AND METHODS}

Tree-ring data were obtained from 3 sites situated in similar edaphic and environmental settings: the 2 settlement sites (Bläckajaure and Munkajaure) situated at $\sim 460$ to $480 \mathrm{~m}$ a.s.l. and a reference area (hereafter referred to as Reference site) situated at $\sim 560$ to $580 \mathrm{~m}$ a.s.l. (Fig. 1). At the 2 settlement sites, trees were sampled within a circular area (radius $300 \mathrm{~m}$ ) centered at the exact location of a decayed and overgrown dwelling hut. At the Reference site, trees were sampled within a broader region with no

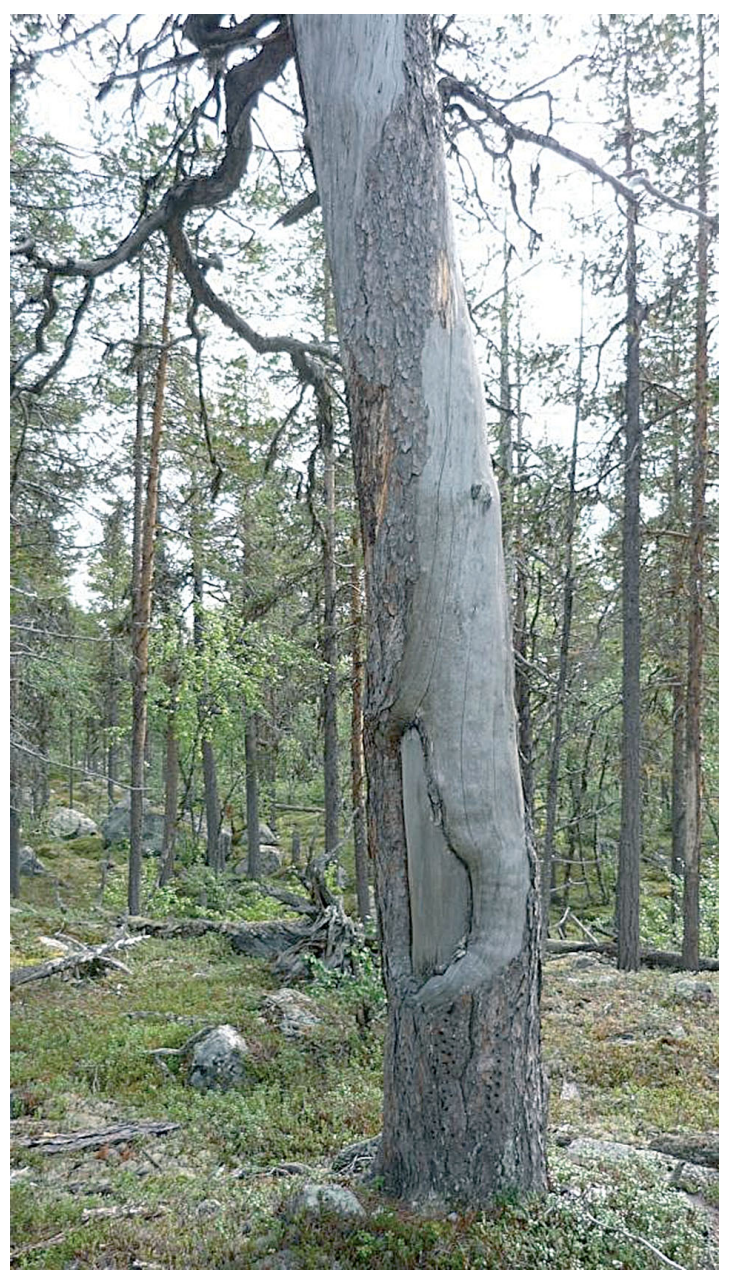

Fig. 2. Pinus sylvestris. Dead Scots pine tree in Munkajaure with an old bark-peeling scar derived from extraction of inner bark, used by the Sami as food and to make storage utensils. Photo: Björn Gunnarson 
Table 1. Comparison of forest characteristics between Reference site and the 2 Sami settlement sites (modified from Josefsson et al. 2010b). Data: mean $\pm \mathrm{SE}$

\begin{tabular}{|lcccccc|}
\hline Sites & $\begin{array}{c}\text { Tree age } \\
(\mathrm{yr})\end{array}$ & Total & $\begin{array}{c}\text { Volume }\left(\mathrm{m}^{3} \mathrm{ha}^{-1}\right) \\
\text { Pine }\end{array}$ & Birch & $\begin{array}{c}\text { Proportion of birch } \\
(\% \text { of total living tree volume) }\end{array}$ & $\begin{array}{c}\text { Volume of dead wood } \\
\left(\mathrm{m}^{3} \mathrm{ha}^{-1}\right)\end{array}$ \\
\hline Reference & $268 \pm 17$ & $72.8 \pm 5.9$ & $53.0 \pm 5.6$ & $0.1 \pm 0.1$ & $0.3 \pm 0.1$ & $19.7 \pm 1.8$ \\
Bläckajaure & $193 \pm 27$ & $81.0 \pm 20.7$ & $72.3 \pm 18.4$ & $1.4 \pm 0.8$ & $2.1 \pm 1.3$ & $7.6 \pm 2.9$ \\
Munkajaure & $144 \pm 19$ & $81.1 \pm 18.7$ & $67.0 \pm 18.2$ & $2.5 \pm 1.4$ & $5.1 \pm 3.5$ & $13.0 \pm 5.9$ \\
\hline
\end{tabular}

traces of human land use. Mean tree age and volume of dead wood are higher and birch volume is lower at the Reference site than at both settlement sites, whereas volume of pine is somewhat lower, and total volume of both living and dead trees rather similar (Table 1). With a $10 \mathrm{~mm}$ increment corer, 1 to 2 radii were taken $\sim 1.3 \mathrm{~m}$ above the ground from living and dead trees. For the living trees, suppressed and injured trees were avoided. To extend the chronologies back in time, all available dead trees were sampled. Discs were cut from the trunks of dead trees lying on the ground with a chainsaw at $\sim 1$ to $1.5 \mathrm{~m}$ above the root collar. Samples from trees with poorly preserved lower sections were cut higher up. In the laboratory, the samples were prepared according to standard dendrochronological techniques (e.g. Stokes \& Smiley 1996), and the annual TRW of each sample were measured with a precision of $\pm 0.01 \mathrm{~mm}$.

To obtain MXD data, thin laths (1.20 mm thick) were cut from samples and treated with alcohol to remove compounds not related to the wood density of the rings (Schweingruber et al. 1978) and then scanned by high energy X-ray beams using an ITRAX wood scanner. The high-resolution grayscale radiographic images thus acquired were calibrated using a calibration wedge from Walesch Electronic, and transformed to density (MXD) data using WinDENDRO software (Guay et al. 1992). From each tree 1 or 2 radii were cross-dated against each other using CATRAS software (Aniol 1991) and averaged into tree-specific time series. These were then cross-dated among the trees, both visually and using COFECHA software (Grissino-Mayer 2001), then averaged into a master chronology for each of the 3 studied sites.

Individual trees usually show differences in growth rates reflecting variations (inter alia) in the microclimate and nutrient availability (Fritts 1976). Furthermore, trees commonly display exponentially declining growth rates with age, i.e. 'classic' biological growth curves, which are partly associated with annual increases in their radial size (Schweingruber 1988). Therefore, to allow data obtained from samples with large differences in growth rates and possi- bly non-relevant growth trends to be combined, the 'raw' (untreated) tree-ring density (or width) data from each tree were detrended by fitting a regional curve function to each ring series. Each value was then divided by the corresponding curve value to generate a series of dimensionless tree-ring growth (TRW and MXD) indices, which were finally averaged into a chronology for each site. This was done, following results and recommendations regarding standardization methods for the specific material and region (cf. Linderholm et al. 2010a), by regional curve standardization (RCS), based on curves derived for the Reference site, at which human impact was assumed to be minimal or non-existent.

RCS has demonstrated ability to preserve longtimescale climate variability in tree-ring chronologies, while removing most of the age-related variance by fitting a single average biological growth curve defined for a larger area to individual ring density series for sites within the region (Esper et al. 2003). When applying this method, all individual ring series should start at the birth year of the tree. When the pith is absent, which is often the case for drilled cores, either the pith offset has to be estimated or it is simply assumed that the first ring measured is the first cambial year. Here we assumed the latter, although this could result in underestimation of the true age of the tree rings, leading to a positive bias in the detrended ring density for young trees (Briffa et al. 1992). The RCS method also relies on the assumption that there is a common growth trend within a region, but this may not be true in an area with varying growth conditions, e.g. if there is a large climate gradient. Therefore, a smoothed 'hugershoff' version (Warren 1980) of the averaged curves was used for the RCS. Here we applied the signal-free approach to minimise trend distortion in chronologies, which is most prevalent at the ends of the chronologies (Melvin \& Briffa 2008). The program used to develop the chronologies was developed by E. Cook and P. Krusic (pers. comm.) and permits the construction of a signal-free chronology using RCS. For each annually resolved detrended TRW and MXD chronology 
(Fig. 4), ARSTAN 40 software (Cook \& Krusic 2005) was used to estimate $95 \%$ confidence intervals for the mean values in each year using a bootstrap technique (Efron 1987).

To estimate the climatic influence on the selected tree-ring parameters, which could then be subtracted from the dataset to quantify the non-climatic impacts (including land-use legacies) on tree growth, TRW and MXD data from the 3 sites were correlated with temperature and precipitation data recorded by the Swedish Meteorological and Hydrological Institute at the closest meteorological station, Kvikkjokk ( $66^{\circ} 89^{\prime} \mathrm{N}, 18^{\circ} 02^{\prime} \mathrm{E}_{;} 314 \mathrm{~m}$ a.s.l.), $30 \mathrm{~km}$ from the study area. Since tree growth may be influenced by environmental conditions in the non-growing season, in addition to conditions during growth periods, monthly total precipitation and average temperatures from May of the year prior to growth to September of the growth year from 1891 to 2008 were used in the correlation analyses. To assess the influence of summer temperature on the Scots pine growth parameters, we created a simple model to estimate how much of the variance in the TRW and MXD datasets could be attributed to warm-season (April to September) temperatures. For this purpose we applied stepwise linear regression, using TRW and MXD as predictands and temperatures of the individual months from April to August as predictors, with probability criteria for entry and removal of $p<0.05$ and $p>0.10$, respectively.

\section{RESULTS}

\subsection{Tree-ring chronologies}

To form 3 separate pairs of TRW and MXD chronologies, a total of 38, 51 and 38 trees were sampled at the Bläckajaure, Munkajaure and Reference sites, respectively. The signal strength of the chronologies was estimated by calculating expressed population signal (EPS) statistics for 50-yr windows moving in $25 \mathrm{yr}$ time steps (cf. Wigley et al. 1984). The EPS represents the percentage of the variance in the hypothetical population signal in the region that is accounted for by each chronology (Fig. 3a,b). Values $>0.85$ are generally regarded as adequate (Wigley et al. 1984). To determine a precise mean value, a reasonable level of chronology replication (sample depth) is required; therefore, we limited the analysis of the TRW and MXD chronologies to EPS levels $\geq 0.85$ except for a critical low value in year 1730 in the Reference chronology. For all 3 chronologies, the sample depth is adequate, as reflected in the high EPS values (Fig. 3c).

For the period from 1550 to 1940 there are no significant differences between the sites, except between 1570 and 1595 in MXD data (Fig. 4b). TRW growth at the Reference site is slightly higher from 1600 to 1940 , and significantly higher between 1940 and 2008, than at Munkajaure and Bläckajaure (Fig. 4a). In contrast, MXD indices are lower at the Reference site than at Munkajaure and Bläckajaure from 1550 to 1750 , and higher from 1750 to the present (Fig. 4b). After 1940 the TRW chronologies for Munkajaure and Bläckajaure exhibit much lower index values than the Reference chronology. For both TRW and MXD there is a significant difference between the Reference and Munkajaure chronologies after 1940 (Fig. 4). No such difference in MXD was found between the Reference and Bläckajaure chronologies (Fig. 4b).

The correlations between Reference, Munkajaure and Bläckajaure TRW and MXD values were calculated using $50 \mathrm{yr}$ running windows for the overlapping period. For TRW (Fig. 4a) the correlation is well above 0.5 except for the period 1710 to 1730 . After ca. 1920, the correlation between the Refer-

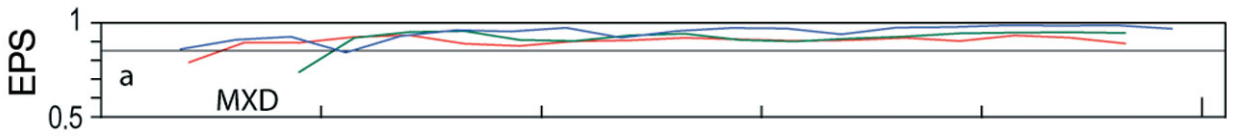

Fig. 3. Expressed population signal (EPS) from Reference (blue), Bläckajaure (red) and Munkajaure (green) sites plotted in averaged 50-yr windows with 25 yr overlap for (a) maximum latewood density (MXD) and (b) tree-ring width (TRW). (c) Sample depth (i.e. no. of overlapping samples) for each site
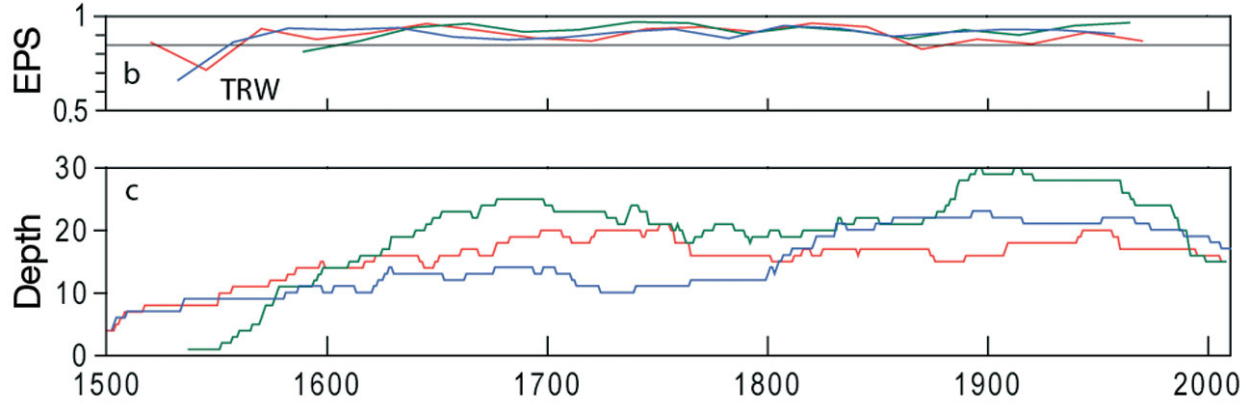

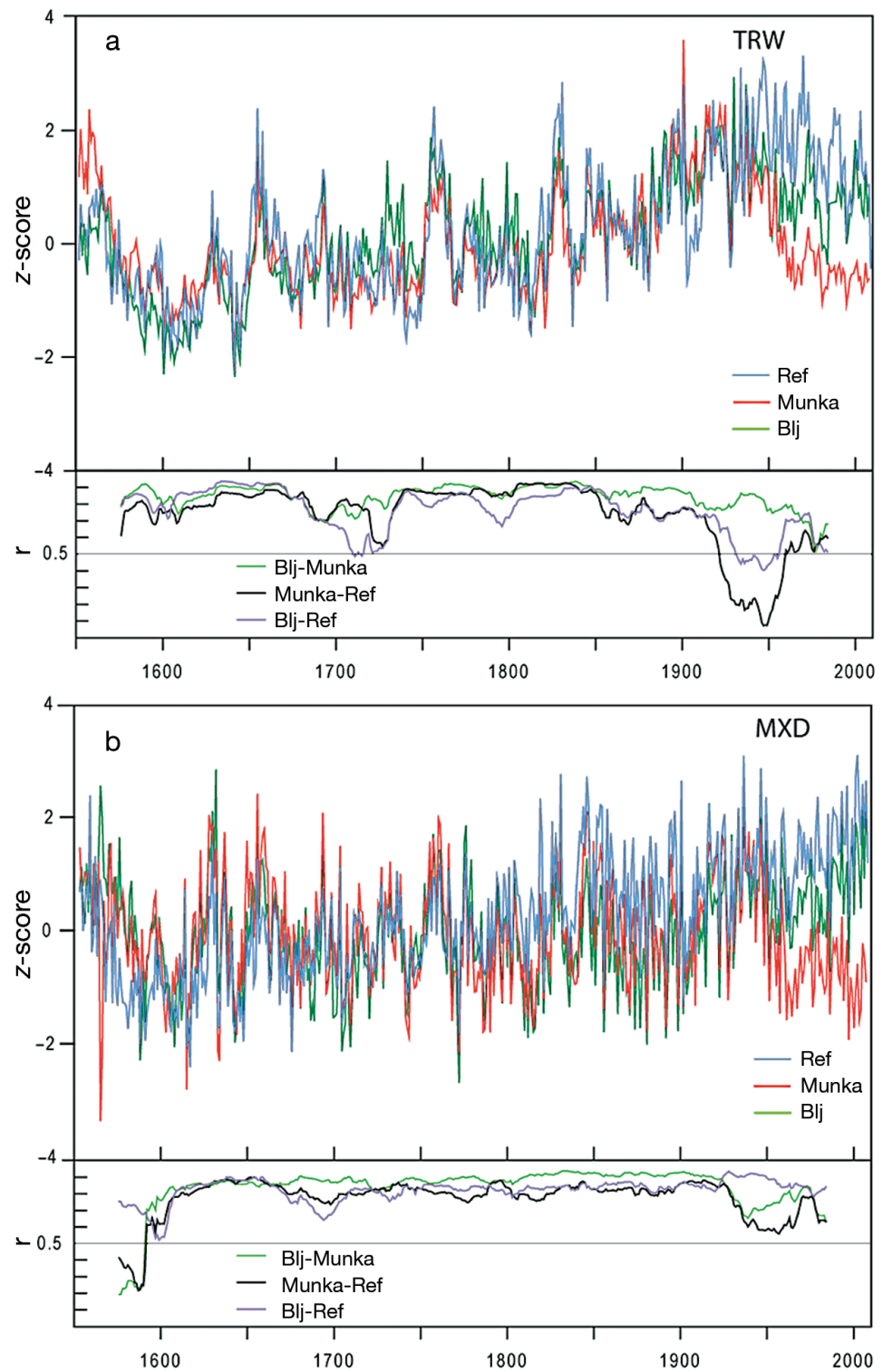

Fig. 4. Signal-free regional curve standardization detrended (a) treering width (TRW) and (b) maximum latewood density (MXD) chronologies (1550-2008) for Reference (Ref, blue), Munkajaure (Munka, red), and Bläckajaure (Blj, green) study sites. Time-series normalised to $z$-scores relative to 1550-1940 period. Lower panels in (a) and (b): correlation values (50-yr windows) of the 3 data sets

ence and Munkajaure TRW values drops rapidly, and during the following decades the correlation is very low, falling to a minimum of 0.1 around 1950. The correlation between the Bläckajaure and the Reference TRW data follows a similar pattern, but is higher for 1920 to 1950. The MXD correlation for Munkajaure against both Bläckajaure and Reference (Fig. $4 \mathrm{~b}$ ) is in general more stable during the analyzed period except around 1600. The explanation for the low correlation is indicated by low EPS values and low sample depth (Fig. 3), which suggests higher year to year variations before 1600. The MXD correlation falls, as for the TRW, in the 1920s, even though it shows higher correlation in general $(>0.5)$.

\subsection{Tree-growth responses to climate}

Both TRW and MXD values from the 3 sites are more strongly associated with temperature than precipitation (Fig. 5). While some significant correlations were found with temperatures of the year preceding growth, the most coherent patterns were between the growth indices and temperatures of the summer of the growth year. Bläckajaure and Reference TRW data showed the most significant correlations with July temperatures. The Reference TRW values were also significantly correlated with temperatures in May, June and August. The correlation pattern differed clearly for the Munkajaure TRW chronology, for which a weak positive correlation was found with July temperatures, but negative correlations of similar strength with May, June and August temperatures. The correlation patterns between Munkajaure MXD values and temperatures also differed from those of the other 2 sites, being significant only for July and August temperatures, while Bläckajaure and Reference MXD values were highly significantly correlated with monthly temperatures from April to August. A few significant correlations were found between precipitation and both TRW and MXD values for each site, except for Bläckajaure TRW, with predominantly positive correlations in winter (December to March) and negative correlations during high summer (July and August).

The annual MXD variability in both the Bläckajaure and Reference chronologies was closely reconstructed by using warm-season temperatures (Fig. 6). Summer temperatures, in all months from May to August for Bläckajaure, and April to August for the Reference site, explain $\sim 60 \%$ of the variance in the MXD data. There is also good correspondence on decadal timescales between the observed and predicted time series, including the increasing trend in the last decades. The model for Munkajaure MXD, 

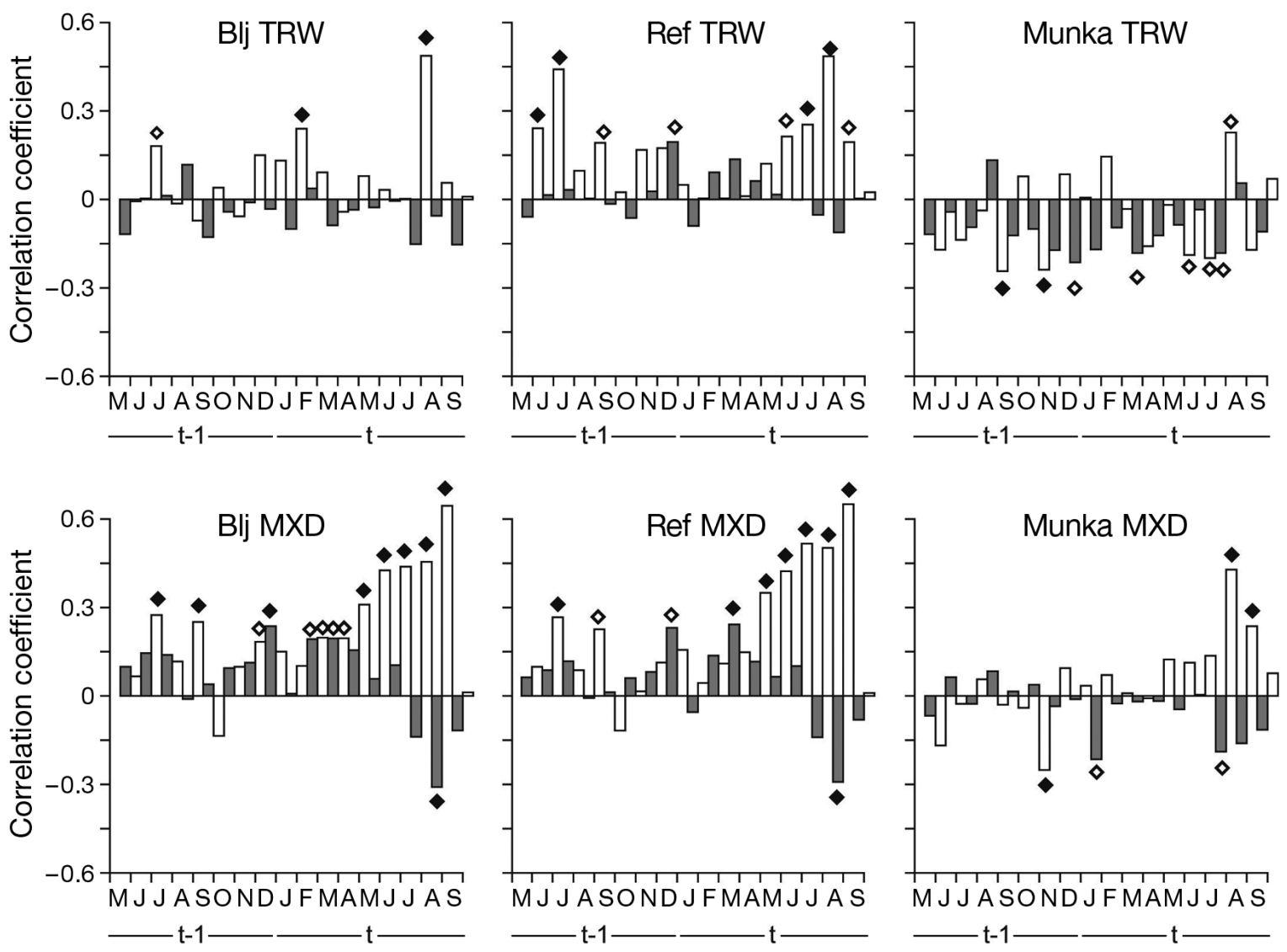

Fig. 5. Correlations between tree-ring width (TRW) and maximum latewood density (MXD) from the 3 study sites (Bläckajaure, Reference, Munkajaure), and both precipitation (grey bars) and temperature (white bars) at Kvikkjokk from May of the year preceding growth $(t-1)$ to September of the growth year $(t)$ for 1891-2008. Significant correlations $-\diamond: \mathrm{p}<0.05, \diamond: \mathrm{p}<0.01$

which was based solely on July temperatures, could only account for a fraction of the observed MXD variability (Fig. 6). It should be noted that the regression analysis indicates serial correlation in the residuals of the TRW models for the Reference and Munkajaure sites (Durbin-Watson statistics for TRW models: Reference $=0.74$, Bläckajaure $=1.01$, Munkajaure $=0.42$ ), but this is not evident in the MXD models (Durbin-Watson statistics for MXD models: Reference $=1.74$, Bläckajaure $=1.76$, Munkajaure $=1.00$ ). Consequently, if a real attempt to model TRW in the Tjeggelvas region was to be made, adjustments for this autocorrelation should be made.

The regression models were only able to capture $\sim 20 \%$ of the variance in observed TRW for all sites. At Bläckajaure and Reference site, only July temperatures were retained in the final models, while at Munkajaure, June through August temperatures were included in the TRW model. It should be noted that experimentation with temperatures for periods other than summer, or precipitation in the TRW and
MXD models gave at most very slight improvements (not shown).

\section{DISCUSSION}

Previous studies have shown that human land use in the Scandinavian mountains several hundreds of years ago caused significant, and sometimes still detectable, changes to the environment (Karlsson et al. 2009, Josefsson et al. 2010b). In forest ecosystems where tree growth and decomposition are slow, e.g. high-altitude forests such as those in the Tjeggelvas NR, this may be especially true. However, this possibility is often overlooked. This study included 2 sites in which the Sami used land for several centuries up to the early 1900s. Our hypothesis was that legacies of low-intensity and long-term land use have affected tree-ring patterns of trees growing close to these sites and thus influenced the climate signals that can be inferred from such trees. Our results, however, show that the proposed relationship is more complex than this hypothesis suggests. 

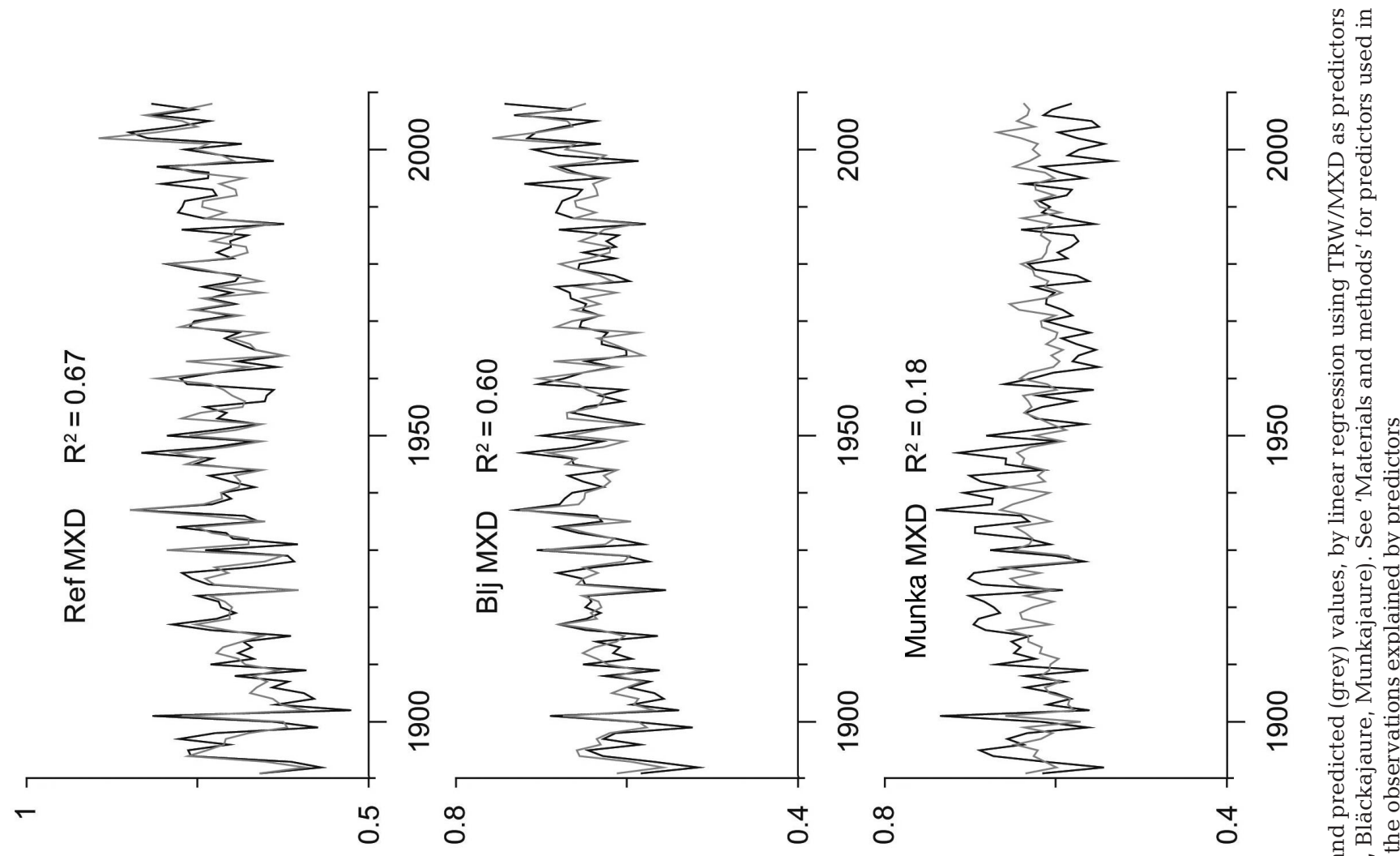

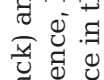
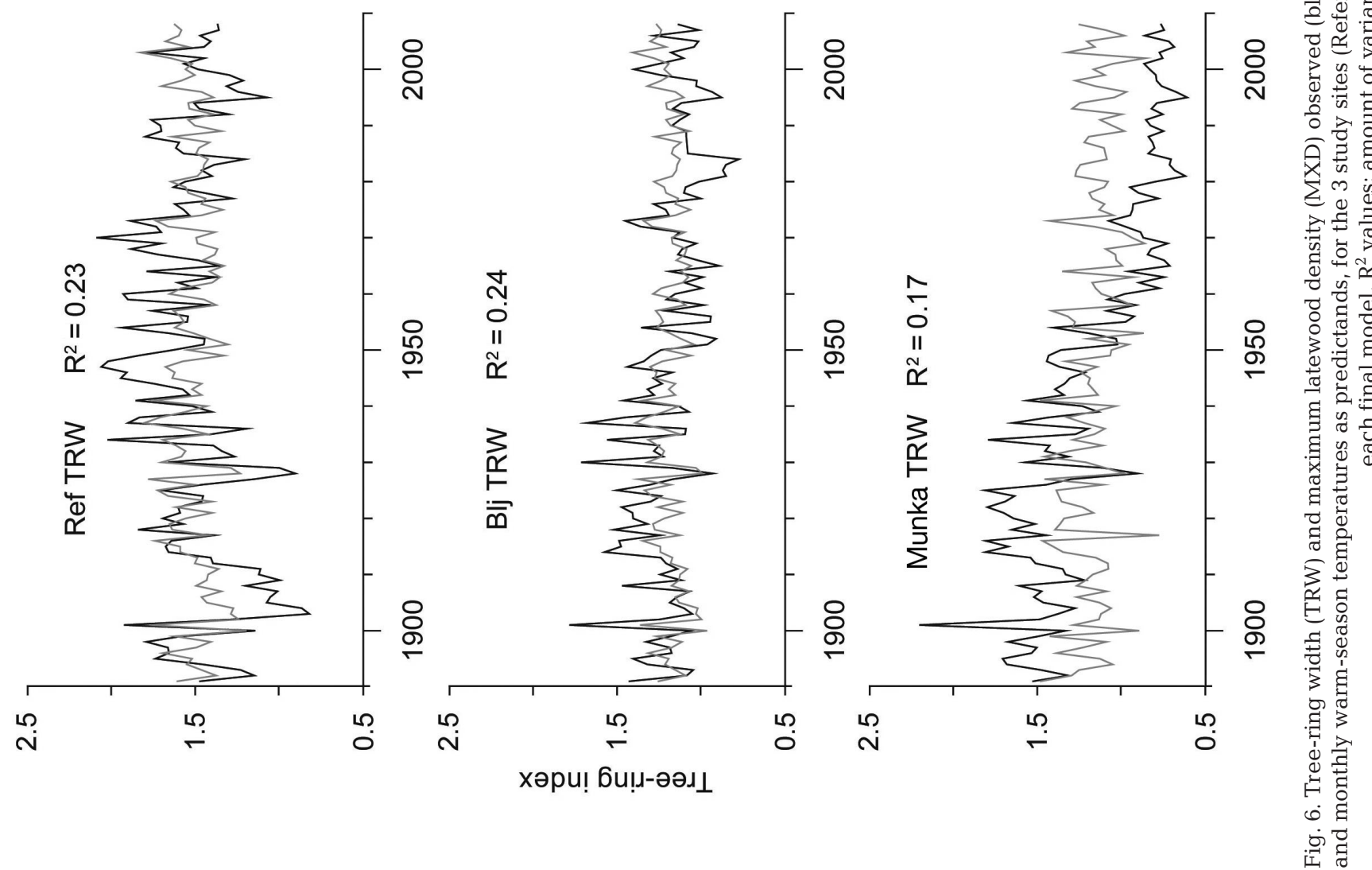


\subsection{Tree-ring patterns and climate}

Contrary to our expectations, the TRW and MXD chronologies from all 3 study sites were very similar from 1550 to 1940, except for slightly higher TRW at the Reference site between 1600 and 1940. The correlation between the Reference chronology and the 2 settlement chronologies is very high except for the initial decades during the 18th century (TRW values: Fig. 4a). Consequently, there are no clear indications of land-use effects on tree-ring patterns of trees growing near Munkajaure or Bläckajaure during this time period. After ca. 1940, however, the 3 chronologies diverge. The Munkajaure and Reference chronologies for both TRW and MXD values show significant deviation from ca. 1940 to the present (Fig. 7).

A key consideration, in the context of this study, is the degree to which (if any) the divergence in treering patterns between the Munkajaure and Reference sites is attributable to climatic factors. The term 'divergence phenomenon' has been discussed in the
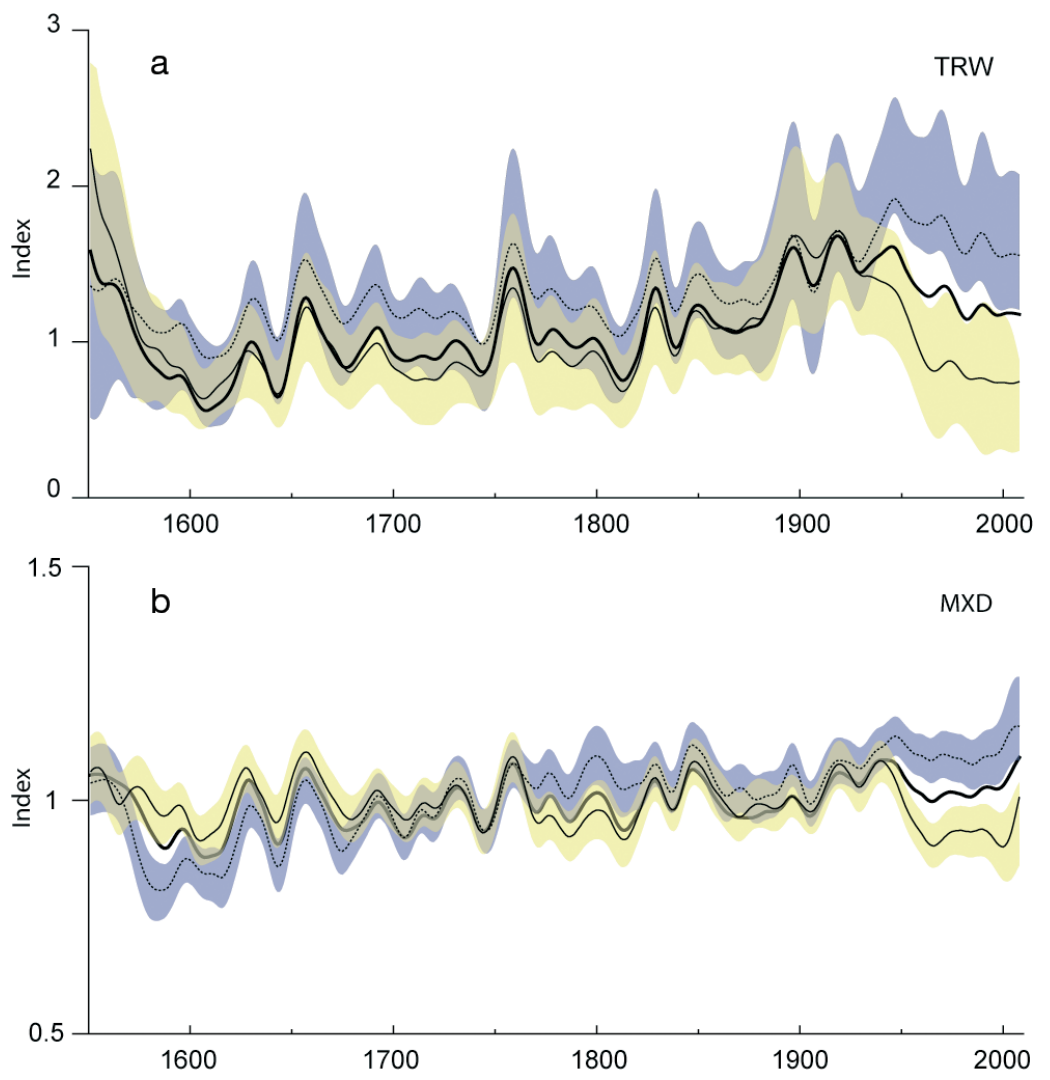

Fig. 7. (a) Tree-ring width (TRW) and (b) maximum latewood density (MXD) chronologies for Reference (dashed line) and Munkajaure (thin solid line) sites. Bold solid line: composite for all 3 study sites, smoothed by a 20 yr cubic spline. Purple and yellow shaded areas: $95 \%$ confidence limits palaeoclimate community (e.g. D'Arrigo et al. 2008) and it is mainly a failure of tree-ring data (established as temperature-responsive) to follow the trend in instrumental temperatures observed over the latter part of the twentieth century. Tree-ring series and particularly ring-density data, largely in parallel with changing temperature in earlier periods, progressively fail to show the increasing trends that would represent a continuing positive response to the strong warming observed during recent decades (Briffa et al. 1998a, Jacoby \& D'Arrigo 1999). This was noted primarily in northern high-latitude and in more extensive regions of northern Europe and Russia. It has been suggested that lack of available moisture (Jacoby et al. 2000, D'Arrigo et al. 2004) during the growth period becomes increasingly influential and can overcome the temperature response in the tree-rings. Other suggestions include reduced atmospheric clarity, localized persistence of spring snow cover and seasonal changes in ozone-related surface UV concentrations (Briffa et al. 1998b, 2004, Vaganov et al. 1999, D'Arrigo et al. 2008).

In this study, tree growth at all 3 sites was more strongly associated with summer temperature than with precipitation (Fig. 5), which is typical for high-latitude forests in the northernmost parts of the boreal zone (cf. Briffa et al. 2002). For the Bläckajaure and Reference sites, the correlation between MXD and temperatures are very strong $\left(r^{2} \geq 0.6\right)$, which is expected along the Scandinavian mountain range (cf. Linderholm et al. 2010a). The Munkajaure site stands out with its low association between both TRW and MXD and the chosen climate parameters. Growth rates declined after 1940 at both Bläckajaure and especially Munkajaure relative to the Reference site (Fig. 4) situated only $\sim 5 \mathrm{~km}$ from the settlement sites. Moreover, while our models successfully reconstructed MXD at the Reference and Bläckajaure sites, the model for Munkajaure only captured a small amount of the observed MXD variability (Fig. 6). It is clear that there is a considerable difference in the growth (and MXD) evolution at Munkajaure relative to the other 2 sites from the 1950 s onwards. If the temperature data from 1950 to 2008 are omitted from the regression analysis, monthly May to August temperatures explain $71 \%$ of 
the variance in Munkajaure MXD, adding to the evidence that factors other than temperature have had a significant influence on tree growth at this site. However, there are no indications of an increased influence of precipitation in the latter period. In fact there are no significant correlations between TRW and temperature/precipitation and only significant correlations between MXD and March ( $\mathrm{p}$ < 0.01) and August $(p<0.01)$ temperatures in the 1950-2008 period. It is clear that the short-term (interannual) variability is quite common in the tree-ring parameters among the sites (Fig. 4). This suggests that on those timescales, the growth influences are similar. Indeed, if focusing on the interannual timescale (by taking the first difference of the tree-ring parameters and temperatures, not shown), summer temperatures (April to September) explain $\sim 40 \%$ of the variance in the TRW data at all sites (including Munkajaure), while they explain 50 to $60 \%$ of the variance in the MXD data ( $50 \%$ at Bläckajaure and Munkajaure and $60 \%$ at Reference site). Thus, it can be assumed that the weak associations between summer temperatures and both TRW and MXD at Munkajaure are caused by the declining growth rates since the 1940s (Figs. $5 \& 6$ ). Since no evidence in the climate data can support this decreasing growth trend, it is likely that factors other than climate have strongly influenced long-term tree growth at this site in the post1940s period.

\subsection{Tree growth and changes in the local environment}

The Reference site is situated at the present tree line. Both settlement sites, however, are situated $\sim 100 \mathrm{~m}$ below the present tree line, but elevation is unlikely to explain the weaker climate responses detected at Munkajaure (Fig. 6), since the MXD climate responses observed at Bläckajaure are consistent with those detected at the Reference site, which would not be the case if elevation was a critical factor. Moreover, MXD climate responses are longer (May to September) and are also less dependent on site characteristics than TRW responses (Gunnarson et al. 2011). If there were differences in site characteristics, such differences would also be apparent before the 1940s. Instead, the weak climate responses and diverging tree-ring patterns observed at Munkajaure may be related to changes in the local environment. For example, increases in tree stand density may buffer climate responses by smoothing climatic extremes, hence high density stands respond to the same climatic factors as low density stands, but less strongly (Helama et al. 2004, 2005). Furthermore, discrete allogenic disturbance events often cause pronounced structural changes in forest ecosystems at local scales (cf. Kuuluvainen 2002, Shorohova et al. 2009), which can have major effects on the growth of the surviving trees. Similar effects, attributed to abrupt changes in a continuous anthropogenic disturbance regime, have been observed on abandoned farmland in Panama (Hooper et al. 2002) and in $60 \mathrm{yr}$ old abandoned Castanea sativa (Mill.) coppice stands in the southern Swiss Alps (Fonti et al. 2006), but not previously (to our knowledge) from areas situated in boreal forest ecosystems.

Anthropogenic disturbance in the forest near the Munkajaure settlement extends far back in time, well before the 1600s. For several centuries various forms of land use in the forest at and near the settlement site created a forest that differed substantially from the surrounding forest landscape; it was younger, more open and there were substantial densities of birch trees (Josefsson et al. 2009, 2010b). However, although the structure and composition of the forest were affected, the growth of individual trees was not, as indicated by our comparisons of TRW and MXD chronologies from all 3 study sites from 1550 to 1940 (Fig. 4). As the time span of the settlement period at Munkajaure overlaps the temporal range of our study, longer time series are needed to examine the effects of settlement establishment. However, the land use was of low-intensity, so structural and compositional changes in the forest probably occurred gradually.

Today, the legacies of former land use close to the settlement are still clearly visible in the local forest structure, e.g. there are few old trees, the volume of dead trees is low and birch is abundant (Table 1). There are also large quantities of bark-peeled trees (Fig. 2) and tall, thin stumps (denoted lichen stumps)the latter created by the Sami reindeer herders when they cut thin trees with abundant arboreal lichen cover to provide food for the reindeer (Berg et al. 2011a). Densities of such stumps near the settlements range from 0 to $150 \mathrm{ha}^{-1}$ (on average $13 \mathrm{ha}^{-1}$, cf. Berg et al. 2011b). When the settlement was abandoned in the early 1900s, regular disturbances spanning long time scales (cutting trees for fire wood and wooden constructions, extraction of various natural resources, and to some extent trampling, grazing and fertilization by the herded reindeer) suddenly stopped. Just a few decades after the settlement was abandoned, the diverging tree-ring patterns among our reconstructed chronologies appeared; hence, the abrupt cessation of human-induced disturbances is a plausi- 
ble explanation for the observed discrepancies between the TRW and MXD chronologies for the Reference area and Munkajaure (Fig. 7). All 3 study sites have most certainly been visited infrequently by reindeer during the last $100 \mathrm{yr}$ since reindeer still pass through the study area during late spring and early autumn. Such occasional presence of reindeer is, however, believed to have negligible effect on forest characteristics.

After the settlement was abandoned, the open forest rapidly became denser, and competition for resources strengthened as the plant biomass per unit area increased. Today, the dwarf shrub Vaccinium myrtillus (L.), which is uncommon in low-productivity pine forests such as those in the Tjeggelvas NR, grows at the settlement site. In addition, the volume of birch is many times higher at Munkajaure than in the forest encompassing the Reference site, whereas the volume of pine is similar (Table 1; Josefsson et al. 2010b). Similar vegetational patterns have been recorded close to a Sami settlement in eastern Finland (Hicks 1995). Presumably, birch regenerated well on the former settlement site when the disturbance ceased.

Past reindeer herding may also have affected the tree species composition at the settlement sites, although only to some extent since the reindeer usually were kept at some distance from the dwelling site (Læstadius 1831, Ruong 1945), similar to other reindeer herding people in Siberia (cf. Vitebsky 2005). Reindeer affect the vegetation in various ways, including grazing on ground vegetation and browsing on leaves and twigs, physical disturbance by trampling and addition of nitrogen from urine and faeces. Consequently, the effect of reindeer on the natural vegetation is complex and also relates to the type of ecosystem and density of animals (Suominen \& Olofsson 2000, Kumpula et al. 2011). At the Munkajaure site, which presumably was used more permanently, it is possible that the overall effect of lowintensity reindeer grazing, trampling and fertilization improved the establishment of birch (cf. Helle et al. 1998, Stark et al. 2007). Furthermore, just as tree species can respond individually to climatic changes (cf. Brooks et al. 1998), they can react very differently to sudden changes in the local environment (Hooper et al. 2002, Dietze \& Clark 2008). For similar reasons to those proposed by Fonti et al. (2006) to explain changes observed in abandoned Castanea sativa coppices after land-use changes, we suggest that as birch became more dominant, the competitive potential changed, favoring birch and certain dwarf shrubs at the expense of Scots pine.
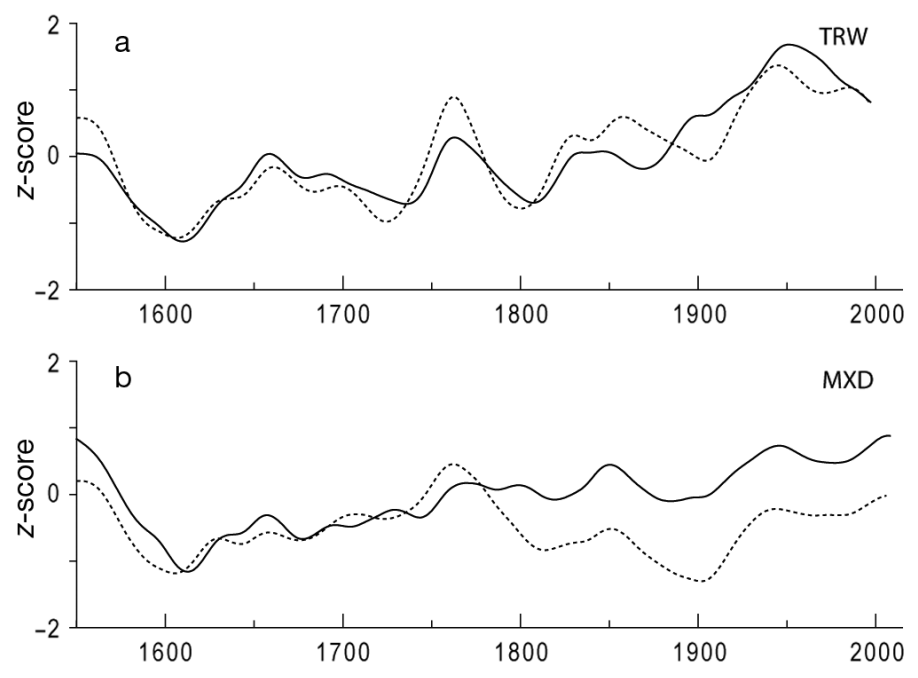

Fig. 8. (a) Tree-ring width (TRW) and (b) maximum latewood density (MXD) chronologies for Reference (solid line) and Torneträsk (dashed line) sites. Chronologies were detrended in the same manner, and forced to have the same mean and SD for 1550-2008. Data were filtered using 50-yr cubic spline

\subsection{Implications for sampling strategies in dendroclimatological research}

In forest ecosystems, it is thus extremely difficult to distinguish effects of ecological factors and climatic fluctuations from effects of human activity (Motta \& Nola 2001, Motta et al. 2006). However, people have clearly utilized forests in northern Scandinavia for thousands of years (Bergman et al. 2003), at varying intensities and spatial scales (Hörnberg et al. 1999, Hellberg et al. 2004, Josefsson et al. 2010b). Landuse intensity has increased or decreased rather abruptly in response to changes in climate and other external factors. This is well known among archaeologists and historical ecologists, but much less so among scholars working in other scientific disciplines.

The history of pre-industrial land use in the studied area is well known compared to other areas in Scandinavia that have been used for dendroclimatological studies. The Reference TRW chronology shows fairly minor discrepancies from the corresponding, intensively examined Torneträsk chronology (Grudd et al. 2002, Grud 2008), but the MXD chronologies show significant deviations from 1775 onwards (Fig. 8). The Torneträsk area, situated $\sim 200 \mathrm{~km}$ north of Tjeggelvas NR, also has a long history of human land use, including Sami reindeer herding, but it has been evaluated in less detail (but see Emanuelsson 1987). Grudd (2008) suggested that the discrepancy 
between MXD and TRW chronologies at Torneträsk was most likely due to major changes in the density of pine trees at the altitudinal tree-line, and noted that during the 20th century, warm season temperatures were not particularly warm in a $1500 \mathrm{yr}$ context. The possibility that the lower MXD values recorded in Torneträsk since 1800 are related to legacies of past human resource utilization cannot be excluded. However, the discrepancies are apparent from the beginning of the 1800s, while in Tjeggelvas the changes between the Munkajaure and Reference sites appear much later, from ca. 1940 until recent times (Fig. 7). Our comparison of these 2 datasets calls for increased knowledge of the land-use history of the sampling sites, and for improved sampling strategies.

We recommend several simple measures to avoid the effects of human disturbance confounding dendroclimatological reconstructions. First, potential sites must be checked for known archaeological remains using official registers, and only areas with no clusters of Sami settlement sites should be selected. Second, a superficial inventory of culturally modified trees (indicating former land use) and forest structure should be made at potential sites. The occurrence of bark-peeled trees, lichen stumps and clusters of birch trees clearly indicates past human disturbance-even in the absence of other archaeological remains. To investigate possible incoherency and inhomogeneity within a sampling site and a tree population, it is further recommended that a network of sites should be initially sampled in order to facilitate the identification of potential management related disturbances and to allow for an objective empirical screening of the data used for dendroclimatic reconstruction.

\section{CONCLUSION}

Tree-ring data have been shown to provide excellent proxies for elucidating late-Holocene climate history due to the high, verifiable, spatial and temporal resolution they offer. This study, however, shows that although tree-ring data mainly reflect interannual differences in summer temperature, they may also reflect other factors, including legacies of past anthropogenic disturbance especially at midfrequencies. Within our study area, trees growing at a site with no history of human land use provide the strongest climate signals, while trees growing at an abandoned settlement site show the weakest signals. We suggest that significantly lower pine tree growth rates at old Sami dwelling sites (as observed at Munkajaure from ca. 1940 to the present) may have been due to rapid changes in traditional Sami land use, or following the abrupt cessation of human-induced disturbances when a settlement was abandoned.

In Fennoscandia and, more generally, in Europe, where there are no forest ecosystems that have been completely undisturbed by human activities, ecological and climatological studies must take into account both legacies of past land use and climate changes. Our study shows that tree growth can be affected by land-use legacies even in forests considered to be virtually untouched. Consequently, without site-specific knowledge of past land use and its legacies, there is a high risk of accidently sampling trees that have been affected by human-induced disturbances in the past. This can in turn bias climate signals inferred from such trees and thus the outcome of climate reconstructions.

Acknowledgements. We thank the Regional County Board of Norrbotten for permission to conduct field work in Tjeggelvas NR. We thank P. Krusic and E. Cook for programming the RCS Signal Free component of ARSTAN and for valuable comments on the statistics. We also thank B. Helamb at Arctic Air for helicopter transportation, and K. Sivertsson for assistance in the field. This research was undertaken with support from VR, Formas and Rymdstyrelsen, and additional funding from the Bert Bolin Climate Center (BBCC).

\section{LITERATURE CITED}

Alexandersson H, Eggertsson Karlström C (2001) Temperaturen och nederbörden i Sverige 1961-1990: referensnormaler. SMHI, Norrköping

Aniol RW (1991) Catras: users manual. Unpublished, Schleswig > Berg A, Gunnarson BE, Östlund L (2011a) 'At this point the lichens in the trees are their only means of survival': the history of tree cutting by native Sami people to feed their reindeer during harsh winters. Environ Hist 17:265-289

> Berg A, Josefsson T, Östlund L (2011b) Cutting of lichen trees: a survival strategy used before the 20th century in northern Sweden. Veget Hist Archeobot 20:125-133

Bergman I, Passe T, Olofsson A, Zackrisson O, Hörnberg G, Hellberg E, Bohlin E (2003) Isostatic land uplift and Mesolithic landscapes: lake-tilting, a key to the discovery of Mesolithic sites in the interior of Northern Sweden. J Archaeol Sci 30:1451-1458

Briffa KR, Bartholin TS, Eckstein D, Jones PD, Karlén W, Schweingruber FH, Zetterberg P (1990) A 1400-year tree ring record of summer temperatures in Fennoscandia. Nature 346:434-439

Briffa KR, Jones PD, Bartholin TS, Eckstein D and others (1992) Fennoscandian summers from AD 500: temperature changes on short and long timescales. Clim Dyn 7 : 111-119

Briffa KR, Schweingruber FH, Jones PD, Osborn TJ and others (1998a) Trees tell of past climates: but are they 
speaking less clearly today? Philos Trans R Soc Lond B Biol Sci 353:65-73

Briffa KR, Schweingruber FH, Jones P, Osborn T (1998b) Reduced sensitivity of recent tree growth to temperature at high northern latitudes. Nature 391:678-682

Briffa KR, Osborn TJ, Schweingruber FH, Jones PD, Shiyatov SG, Vaganov EA (2002) Tree-ring width and density data around the Northern Hemisphere. I. Local and regional climate signals. Holocene 12:737-757

Briffa KR, Osborn TJ, Schweingruber FH (2004) Large-scale temperature inferences from tree rings: a review. Global Planet Change 40:11-26

Brooks JR, Flanagan LB, Ehleringer JR (1998) Responses of boreal conifers to climate fluctuations: indications from tree-ring widths and carbon isotope analyses. Can J Res 28:524-533

Cook ER, Krusic PJ (2005) Program ARSTAN: a tree-ring standardization program based on detrending and autoregressive time series modeling with interactive graphics. Tree-Ring Laboratory, Lamont-Doherty Earth Observatory, Columbia University, Palisades, NY

> D'Arrigo R, Mashig E, Frank D, Jacoby G, Wilson R (2004) Reconstructed warm season temperatures for Nome, Seward Peninsula, Alaska since AD 1389. Geophys Res Lett 31:L09202

- D'Arrigo R, Wilson R, Liepert B, Cherubini P (2008) On the 'divergence problem' in northern forests: a review of the tree-ring evidence and possible causes. Global Planet Change 60:289-305

Dietze MC, Clark JS (2008) Changing the gap dynamics paradigm: vegetative regeneration control on forest response to disturbance. Ecol Monogr 78:331-347

- Efron B (1987) Better bootstrap confidence intervals. J Am Stat Assoc 82:171-185

Emanuelsson U (1987) Human influence on vegetation in the Torneträsk area during the last three centuries. Ecol Bull 38:95-111

> Eronen M, Zetterberg P, Briffa KR, Lindholm M, Meriläinen J, Timonen M (2002) The supra-long Scots pine tree-ring record for Finnish Lapland. I. Chronology construction and initial inferences. Holocene 12:673-680

Esper J, Cook ER, Schweingruber FH (2002) Low-frequency signals in long tree-ring chronologies for reconstructing past temperature variability. Science 295:2250-2253

Esper J, Cook ER, Krusic PJ, Peters K, Schweingruber F (2003) Tests of the RCS methods for preserving lowfrequency variability in long tree-ring chronologies. Tree-Ring Res 59:81-98

Fonti P, Cherubini P, Rigling A, Weber P, Biging G (2006) Tree rings show competition dynamics in abandoned Castanea sativa coppices after land-use changes. J Veg Sci 17:103-112

Foster DR, Swanson F, Aber JD, Burke I, Brokaw N, Tilman D, Knapp A (2003) The importance of land-use legacies to ecology and conservation. Bioscience 53:77-88

Fredén C (1994) National atlas of Sweden. Geology. Almqvist \& Wiksell International, Stockholm

Fritts HC (1976) Tree-Rings and Climate. Academic Press, London

Gouirand I, Linderholm HW, Moberg A, Wohlfarth B (2008) On the spatiotemporal characteristics of Fennoscandian tree-ring based summer temperature reconstructions. Theor Appl Climatol 91:1-25

Grissino-Mayer HD (2001) Evaluating crossdating accuracy: a manual and tutorial for the computer program
COFECHA. Tree-Ring Res 57:205-221

> Grudd H (2008) Torneträsk tree-ring width and density AD 500-2004: a test of climatic sensitivity and a new 1500year reconstruction of north Fennoscandian summers. Clim Dyn 31:843-857

Grudd H, Briffa KR, Karlén W, Bartholin TS, Jones PD, Kromer B (2002) A 7400-year tree-ring chronology in northern Swedish Lapland: natural climate variability expressed on annual to millennial timescales. Holocene 12:657-665

Guay R, Gagnon R, Morin H (1992) A new automatic and interactive tree measurement system based on a line scan camera. For Chron 68:138-141

Gunnarson BE, Linderholm HW (2002) Low-frequency summer temperature variation in central Sweden since the tenth century inferred from tree rings. Holocene 12: $667-671$

Gunnarson BE, Linderholm HW, Moberg A (2011) Improving a tree-ring reconstruction from west-central Scandinavia: 900 years of warm-season temperatures. Clim Dyn 36:97-108

Helama S, Lindholm M, Timonen M, Meriläinen J, Eronen M (2002) The supra-long Scots pine tree-ring record for Finnish Lapland. 2. Interannual to centennial variability in summer temperatures for 7500 years. Holocene 12: $681-687$

Helama S, Lindholm M, Timonen M, Eronen M (2004) Detection of climate signal in dendrochronological data analysis: a comparison of tree-ring standardization methods. Theor Appl Climatol 79:239-254

Helama S, Timonen M, Lindholm M, Meriläinen J, Eronen M (2005) Extracting long-period climate fluctuations from tree-ring chronologies over timescales of centuries to millennia. Int J Climatol 25:1767-1779

Hellberg E, Niklasson M, Granström A (2004) Influence of landscape structure on patterns of forest fires in boreal forest landscapes in Sweden. Can J For Res 34:332-338

Helle T, Kajala L, Niva A, Särkelä M (1998) Poron laidunnuksen vaikutus tunturikoivikoiden rakenteeseen. In: Hyppönen M, Penttilä T, Poikajärvi H (eds) Poron vaikutus metsä- ja tunturiluontoon. Metsäntutkimuslaitoksen Tiedonantoja 678:132-141

Hicks S (1995) The history of a wilderness area in Finnish Lapland as revealed by pollen analysis. Arctic Cent Publ 7:126-140

Hooper E, Condit R, Legendre P (2002) Responses of 20 native tree species to reforestation strategies for abandoned farmland in Panama. Ecol Appl 12:1626-1641

Hörnberg G, Östlund L, Zackrisson O, Bergman I (1999) The genesis of two Picea-Cladina forests in northern Sweden. J Ecol 87:800-814

Jacoby GC, Lovelius NV, Shumilov OI, Raspopov OM, Karbainov JM, Frank DC (2000) Long-term temperature trends and tree growth in the Taymir region of northern Siberia. Quat Res 53:312-318

$>$ Jones PD, Briffa KR, Barnett TP, Tett SFB (1998) High resolution palaeoclimatic records for the last millennium: interpretation, integration and comparison with General Circulation Model control-run temperatures. Holocene 8:455-471

> Josefsson T, Hörnberg G, Östlund L (2009) Long-term human impact and vegetation changes in a boreal forest reserve: implications for the use of protected areas as ecological references. Ecosystems 12:1017-1036

Josefsson T, Bergman I, Östlund L (2010a) Quantifying Sami 
settlement and movement patterns in northern Sweden 1700-1900. Arctic 63:141-154

Josefsson T, Gunnarson BE, Liedgren L, Bergman I, Östlund L (2010b) Historical human influence on forest composition and structure in boreal Fennoscandia. Can J For Res 40:872-884

Karlsson H, Shevtsova A, Hörnberg G (2009) Vegetation development at a mountain settlement site in the Swedish Scandes during the late Holocene: palaeoecological evidence of human-induced deforestation. Veget Hist Archaeobot 18:297-314

Kumpula J, Stark S, Holand Ø (2011) Seasonal grazing effects by semi-domesticated reindeer on subarctic mountain birch forests. Polar Biol 34:441-453

Kuuluvainen T (2002) Disturbance dynamics in boreal forests: defining the ecological basis of restoration and management of biodiversity. Silva Fenn 36:5-11

Læstadius P (1831) Journal af Petrus Laestadius för första året af hans tjenstgöring såson missionaire i Lappmarken. Haeggström, Stockholm

Liedgren LG, Josefsson T, Östlund L (2009) Samisk byggnadskultur: timrade kåtor och exemplet Bläckajaure. Arkeologi i Norr 11:115-144

Linderholm HW, Björklund J, Seftigen K, Gunnarson BE and others (2010a) Dendroclimatology in Fennoscandia: from past accomplishments to future potentials. Clim Past 6: 93-114

Linderholm HW, Gunnarson BE, Liu Y (2010b) Comparing Scots pine tree-ring proxies and detrending methods among sites in Jämtland, west-central Scandinavia. Dendrochronologia 28:239-249

Mann ME, Bradley RS, Hughes MK (1999) Northern Hemisphere temperatures during the past millennium: inferences, uncertainties and limitations. Geophys Res Lett 26:759-762

McCarroll D, Jalkanen R, Hicks S, Tuovinen M and others (2003) Multiproxy dendroclimatology: a pilot study in northern Finland. Holocene 13:829-838

Melvin TM, Briffa KR (2008) 'A 'signal-free' approach to dendroclimatic standardisation. Dendrochronologia 26: 71-86

Motta R, Nola P (2001) Growth trends and dynamics in subalpine forest stands in the Varaita Valley (Piedmont, Italy) and their relationships with human activities and global change. J Veg Sci 12:219-230

Motta R, Morales M, Nola P (2006) Human land-use, forest dynamics and tree growth at the tree line in the western Italian Alps. Ann Sci 63:739-747

Östlund L, Ericsson TS, Zackrisson O, Andersson R (2003) Traces of past Sami forest use: an ecological study of

Editorial responsibility: Nils Chr. Stenseth, Oslo, Norway culturally modified trees and earlier land use within a boreal forest reserve. Scand J For Res 18:78-89

Rönnow C (1944) Renskötsel hos Arjeplogs fjällsamer med särskild hänsyn till Arjeplogs lappby: naturgeografiska förutsättningar och utformning. Meddelanden från Lunds Universitets Geografiska Institution 219:25-93

Ruong I (1945) Studier i lapsk kultur i Pite lappmark och angränsande områden. PA Norstedt \& Söner, Stockholm

Sano M, Furuta F, Sweda T (2009) Tree-ring-width chronology of Larix gmelinii as an indicator of changes in early summer temperature in east-central Kamchatka. J For Res 14:147-154

Schweingruber FH (1988) Tree rings: basics and applications of dendrochronology. Kluwer, London

Schweingruber FH, Fritts HC, Bräker OU, Drew LG, Schär E (1978) The X-ray technique as applied to dendroclimatology. Tree-Ring Bull 38:61-91

Shorohova E, Kuuluvainen T, Kangur A, Jogiste K (2009) Natural stand structures, disturbance regimes and successional dynamics in the Eurasian boreal forests: a review with special reference to Russian studies. Ann For Sci 66:201

Stark S, Julkunen-Tiitto R, Kumpula J (2007) Ecological role of reindeer summer browsing in the mountain birch (Betula pubescens ssp. czerepanovii) forests: effects on plant defense, litter decomposition, and soil nutrient cycling. Oecologia 151:486-498

Stokes MA, Smiley TL (1996) An introduction to tree-ring dating. University of Arizona Press, Tucson, AZ

Suominen O, Olofsson J (2000) Impacts of semi-domesticated reindeer on structure of tundra and forest communities in Fennoscandia: a review. Ann Zool Fenn 37:233-249

Tuovinen M, McCarroll D, Grudd H, Jalkanen R, Los S (2009) Spatial and temporal stability of the climatic signal in northern Fennoscandian pine tree-ring width and maximum density. Boreas 38:1-12

> Vaganov EA, Hughes MK, Kirdyanov AV, Schweingruber FH, Silkin PP (1999) Influence of snowfall and melt timing on tree growth in subarctic Eurasia. Nature 400: $149-151$

Vitebsky P (2005) The reindeer people: living with animals and spirits in Siberia. Houghton Mifflin Company, New York, NY

Warren WG (1980) On removing the growth trend from dendrochronological data. Tree-Ring Bull 40:35-44

Wigley TML, Briffa KR, Jones PD (1984) On the average value of correlated time series, with applications in dendroclimatology and hydrometeorology. J Clim Appl Meteorol 23:201-213

Submitted: May 31, 2011; Accepted: January 11, 2012 Proofs received from author(s): May 14, 2012 